\title{
New crystal-chemical data on zincoberaunite from Krásno near Horní Slavkov (Czech Republic)
}

\author{
Jaromír TVRDÝ1*, Jakub PLÁŠIL², Radek ŠKODA \\ ${ }^{1}$ Department of Geological Sciences, Faculty of Science, Masaryk University, Kotlářská 2, 61137 Brno, Czech Republic; \\ jt.geologie@gmail.com \\ ${ }^{2}$ Institute of Physics, Academy of Sciences of the Czech Republic, v.v.i., Na Slovance 2, 18221 Prague 8, Czech Republic \\ * Corresponding author
}

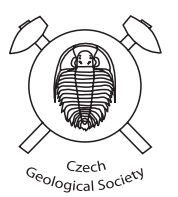

A study of zincoberaunite from Krásno near Horní Slavkov (Czech Republic) provided new chemical and structural data of this rare member of the beraunite group. The studied material is monoclinic, space group $C 2 / c$, with $a=20.3440(19) \AA$, $b=5.1507(3) \AA, c=19.1361(15) \AA, \beta=93.568(8)^{\circ}, V=2001.3(3) \AA^{3}, Z=4$. Based on refined site occupancies and bond-valence considerations, the structural formula is $\left(\mathrm{Zn}_{0.81} \mathrm{Al}_{0.19}\right)(\mathrm{OH})_{2}\left(\mathrm{Fe}_{0.61} \mathrm{Al}_{0.39}\right)(\mathrm{OH})_{2}\left(\mathrm{H}_{2} \mathrm{O}\right)_{2}\left(\mathrm{Fe}_{1.52} \mathrm{Al}_{0.48}\right)\left(\mathrm{H}_{2} \mathrm{O}\right)_{2}\left(\mathrm{Fe}_{1.72} \mathrm{Al}_{0.28}\right)$ $(\mathrm{OH})\left(\mathrm{PO}_{4}\right)_{3.83}\left(\mathrm{AsO}_{4}\right)_{0.17}\left(\mathrm{H}_{2} \mathrm{O}\right)_{2}$. Electron-microprobe analyses support the obtained results. However, keeping the same cation occupancy at the $M 2-M 4$ sites, the ratio of $\mathrm{Al}^{3+}$ to $\mathrm{Me}^{2+}$ at the $M 1$ site requires the presence of divalent cations as follows: $\left(\mathrm{Zn}_{0.57} \mathrm{Fe}_{0.24} \mathrm{Al}_{0.19}\right)_{\Sigma 1.00}\left(\mathrm{Fe}_{3.85} \mathrm{Al}_{1.15}\right)_{\Sigma 5.00}\left[\left(\mathrm{PO}_{4}\right)_{3.89}\left(\mathrm{AsO}_{4}\right)_{0.10}\left(\mathrm{SiO}_{4}\right)_{0.01}\right]_{\Sigma 4.00}\left[(\mathrm{OH})_{4.59} \mathrm{~F}_{0.24} \mathrm{O}_{0.17}\right]_{\Sigma 5.00}\left(\mathrm{OH}_{2}\right)_{4.00} \cdot 2 \mathrm{H}_{2} \mathrm{O}$. Individual prismatic zincoberaunite crystals exhibit a chemical zonation manifested by increasing Fe and decreasing $\mathrm{Zn}$ and $\mathrm{Al}$ contents from cores to rims. The mineral composition is close to the $\mathrm{Zn}-\mathrm{Al}$-rich members of the beraunite group known from the same locality, but in this case, dominant occupancy of $\mathrm{Zn}$ at the $M 1$ site was confirmed. With its increased aluminium content, zincoberaunite from Krásno differs significantly from the holotype specimen described from Hagendorf South pegmatite in Germany. The most prominent Raman bands are in good agreement with data published for related members of the beraunite group. Structure refinement $(R=3.56 \%$ for 1906 observed unique reflections) revealed three different types of $\mathrm{OH}$ or $\mathrm{H}_{2} \mathrm{O}$, which play distinct role in structure bonding.

Keywords: zincoberaunite, phosphate, crystal structure, Raman spectra, Krásno near Horni Slavkov, Czech Republic

Received: 13 November 2019; accepted: 3 March 2020; handling editor: J. Cempirek

The online version of this article (doi: 10.3190/jgeosci.296) contains supplementary electronic material

\section{Introduction}

Zincoberaunite is a member of the beraunite group of minerals with the general formula $M 1 M 2 M 3_{2} M 4_{2}\left(\mathrm{PO}_{4}\right)_{4}(\mathrm{OH})_{5} \cdot 6 \mathrm{H}_{2} \mathrm{O}$. Currently, the beraunite group includes four members listed in Tab. 1. Zincoberaunite, ideally $\mathrm{ZnFe}_{5}^{3+}\left(\mathrm{PO}_{4}\right)_{4}(\mathrm{OH})_{5} \cdot 6 \mathrm{H}_{2} \mathrm{O}$, was described as a new mineral from the Hagendorf South granitic pegmatite, Bavaria, Germany, few years ago (Chukanov et al. 2016). A Zn- and Al-rich variety of beraunite was observed in Krásno near Horní Slavkov (Czech Republic) in 2006 already (Sejkora et al. 2006), but the contents of both elements were not high enough for definition of a new species. Average $\mathrm{Zn}$ contents in the holotype sample of tvrdýite, ideally $\mathrm{Fe}^{2+} \mathrm{Fe}^{3+}{ }_{2} \mathrm{Al}_{3}\left(\mathrm{PO}_{4}\right)_{4}\left(\mathrm{OH}_{2}\right)_{4} \cdot 2 \mathrm{H}_{2} \mathrm{O}$, and associated Al-rich beraunite from the same locality are 0.52 and $0.64 a p f u$, respectively. However, there is no $\mathrm{Zn}$ dominance at any specific site and, moreover, $\mathrm{Zn}$ occupies the $M 1, M 3$ and $M 4$ sites (Sejkora et al. 2016). In this study of a sample from Krásno we present different cation par- titioning behaviour in beraunite-type mineral structure; crystal-structure refinement supplemented by quantitative electron-microprobe analyses (EPMA) and Raman spectroscopy proved that while $\mathrm{Zn}^{2+}$ enters preferentially the $M 1$ site, $\mathrm{Al}^{3+}$ is not dominant at any specific position. Therefore, the mineral can be classified as Al-rich zincoberaunite; results of our study are given in this paper.

\section{Occurrence}

The $\mathrm{Sn}-\mathrm{W}$ ore district of Krásno-Horní Slavkov is a famous area of ancient mining in the Slavkovský les Mts., located in Western Bohemia, Czech Republic (Beran and Sejkora 2006). Mining activities since the $12^{\text {th }}$ century were documented there (Beran 1995). The ore mineralisation is bound to greisenized cupolas of
Tab. 1 Members of the beraunite group

\begin{tabular}{lll}
\hline Beraunite & $\mathrm{Fe}^{2+} \mathrm{Fe}^{3+}{ }_{5}\left(\mathrm{PO}_{4}\right)_{4}(\mathrm{OH})_{5} \cdot 6 \mathrm{H}_{2} \mathrm{O}$ & Breithaupt (1840, 1841) \\
Eleonorite & $\mathrm{Fe}^{3+}\left(\mathrm{PO}_{4}\right)_{4} \mathrm{O}(\mathrm{OH})_{4} \cdot 6 \mathrm{H}_{2} \mathrm{O}$ & Chukanov et al. (2017) \\
Tvrdýite & $\mathrm{Fe}^{2+} \mathrm{Fe}^{3+} \mathrm{Al}_{2}\left(\mathrm{PO}_{4}\right)_{4}(\mathrm{OH})_{5}\left(\mathrm{H}_{2} \mathrm{O}\right)_{4} \cdot 2 \mathrm{H}_{2} \mathrm{O}$ & Sejkora et al. (2016) \\
Zincoberaunite & $\mathrm{ZnFe}_{5}^{3+}\left(\mathrm{PO}_{4}\right)_{4}(\mathrm{OH})_{5} \cdot 6 \mathrm{H}_{2} \mathrm{O}$ & Chukanov et al. (2016) \\
\hline
\end{tabular}


Variscan granitic bodies emplaced into migmatised Proterozoic paragneisses. These granitoids belong to the large composite batholith that underlies the entire Krušné hory/Erzgebirge block in depth. The largest cupola is the Huber Stock; its apical parts were completely metasomatised to a compact greisen with disseminated ore minerals (Jarchovský 2006). Greisens and surrounding gneisses are penetrated by centimetre- to decimetre-thick quartz veins often containing rich $\mathrm{Sn}-\mathrm{W}$ mineralisation. Until 1991, the Stannum shaft and a small-open pit exploited the Huber Stock.

Relatively common minor components of greisen bodies and associated quartz veins in the Krásno-Horní Slavkov area are phosphate accumulations (Beran and Sejkora 2006). Phosphate masses range from several millimetres up to $1 \mathrm{~m}$ in size and consist of dominant fluorapatite and triplite, occasionally also accompanied by frondelite (Sejkora et al. 2006). Their late hydrothermal to probably supergene alterations led to the formation of a number of secondary mineral phases, including first described new phosphates iangreyite (Mills et al. 2011), krásnoite (Mills et al. 2012), tvrdýite (Sejkora et al. 2016), and kenngottite (Sejkora et al. 2019b).

The studied specimen is $8 \times 5 \times 5 \mathrm{~cm}$ in size and was collected in the Huber open pit during the last phase of mining of Sn-W ores in the late 1980s. It is represented by white, partly limonitised gangue quartz containing fluorapatite of two different types, occurring as (i) several fresh bottle-green isometric grains up to $7 \mathrm{~mm}$ and as (ii) an irregular fine-grained pinkish-beige aggregate of c. $30 \times 15 \mathrm{~mm}$ in size. Zincoberaunite occurs in a small cavity (dimensions $c .15 \times 10 \mathrm{~mm}$ ) as thin acicular crystals grouped in radiating aggregates up to $2 \mathrm{~mm}$ in size. The aggregates have a glassy lustre and are dark yellowish-grey in the centres, grading into yellowish-brown on the margins (Fig. 1). The specimen and the analysed epoxy mount are stored in the research collection of the first author (JT) under the number T-121.

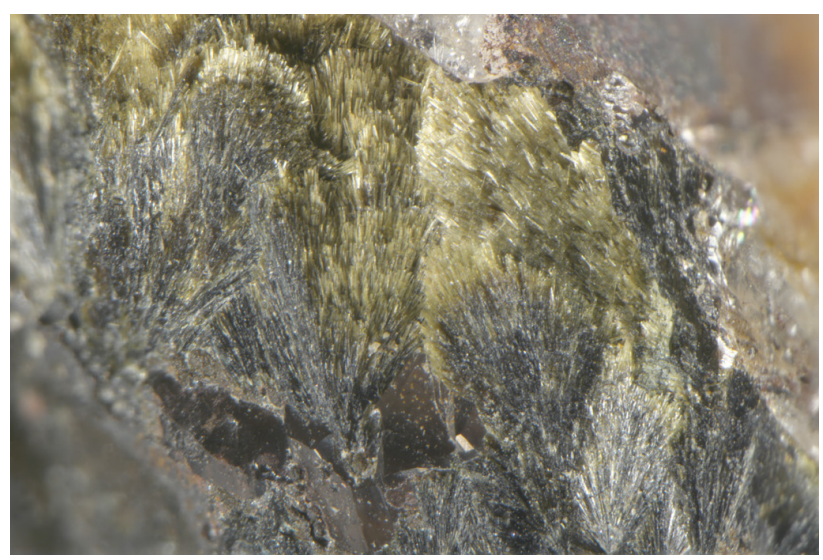

Fig. 1 Zincoberaunite from Krásno, Czech Republic. Field of view is $4 \mathrm{~mm}$ wide.

\section{Chemical composition}

The chemical composition of zincoberaunite was determined on polished and carbon-coated fragments mounted in an epoxy cylinder using a Cameca SX 100 electron microprobe (Joint laboratory of Masaryk University Brno and of the Czech Geological Survey). The instrument was operated in wavelength-dispersive mode at accelerating voltage of $15 \mathrm{keV}$, beam current of $10 \mathrm{nA}$, and beam diameter of $5 \mu \mathrm{m}$ from 13 analytical points (Fig. 2). The following X-ray lines and standards were selected; $K_{\alpha}$ lines: P (fluorapatite), $\mathrm{Al}$ (andalusite), $\mathrm{K}$ (orthoclase), $\mathrm{Zn}$ (gahnite), $\mathrm{Ni}$ (syn. $\mathrm{Ni}_{2} \mathrm{SiO}_{4}$ ), $\mathrm{Fe}$ (ferrocolumbite), $\mathrm{Mg}$ (syn. $\mathrm{Mg}_{2} \mathrm{SiO}_{4}$ ), $\mathrm{Na}$ (albite), $\mathrm{Si}, \mathrm{Ca}$ (wollastonite), $\mathrm{Mn}$ (spessartine), $\mathrm{Ti}$ (syn. $\mathrm{TiO}_{2}$ ), $\mathrm{S}$ (syn. $\mathrm{SrSO}_{4}$ ), $\mathrm{Cl}$ (vanadinite) and $\mathrm{F}$ (topaz), $\mathrm{L}_{\alpha}$ lines: $\mathrm{As}, \mathrm{Cu}$ (lammerite), $\mathrm{Sr}$ (syn. $\mathrm{SrSO}_{4}$ ), $\mathrm{Ba}$ (baryte). Contents of $\mathrm{Na}, \mathrm{K}, \mathrm{Ca}, \mathrm{Mg}, \mathrm{Ni}, \mathrm{Cu}$, $\mathrm{Ba}, \mathrm{Ti}, \mathrm{S}$ and $\mathrm{Cl}$ were below detection limits $(\sim 0.05-0.10$ wt. \%). Counting times were $10-20 \mathrm{~s}$ on peak and half of this time for each background position. The measured $\mathrm{X}$-ray intensities were processed for matrix effects using the X- $\varphi$ correction routine (Merlet 1994). Water could not be analysed directly because of the very small amount of material available; it was calculated on the basis of $17 \mathrm{H} \mathrm{apfu}$ from the crystal-structure analysis, corrected for partial substitution of $\mathrm{F}$ and $\mathrm{O}$ for $\mathrm{OH}$.

The chemical composition of zincoberaunite from Krásno is given in Tab. 2, together with published data for holotype samples of the same mineral (Chukanov et al. 2016), tvrdýite and associated Al-rich beraunite (Sejkora et al. 2016). The analytical results show a slight chemical heterogeneity of the sample and are in a good agreement with the crystal structure analysis (see below). However, keeping the same cation occupancy in the

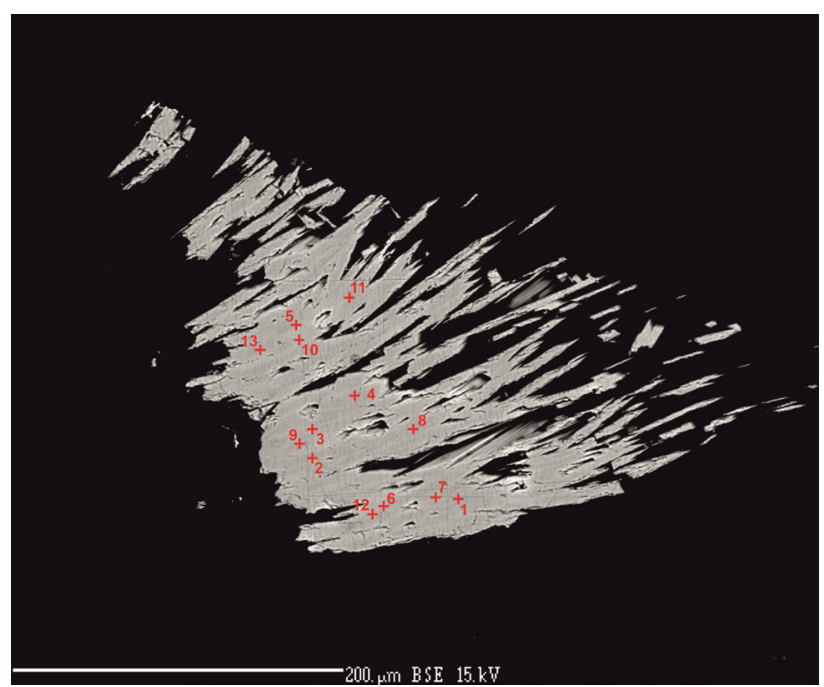

Fig. 2 Electron-microprobe image (BSE mode) of zincoberaunite from Krásno; individual analytical points are labelled with numbers. 


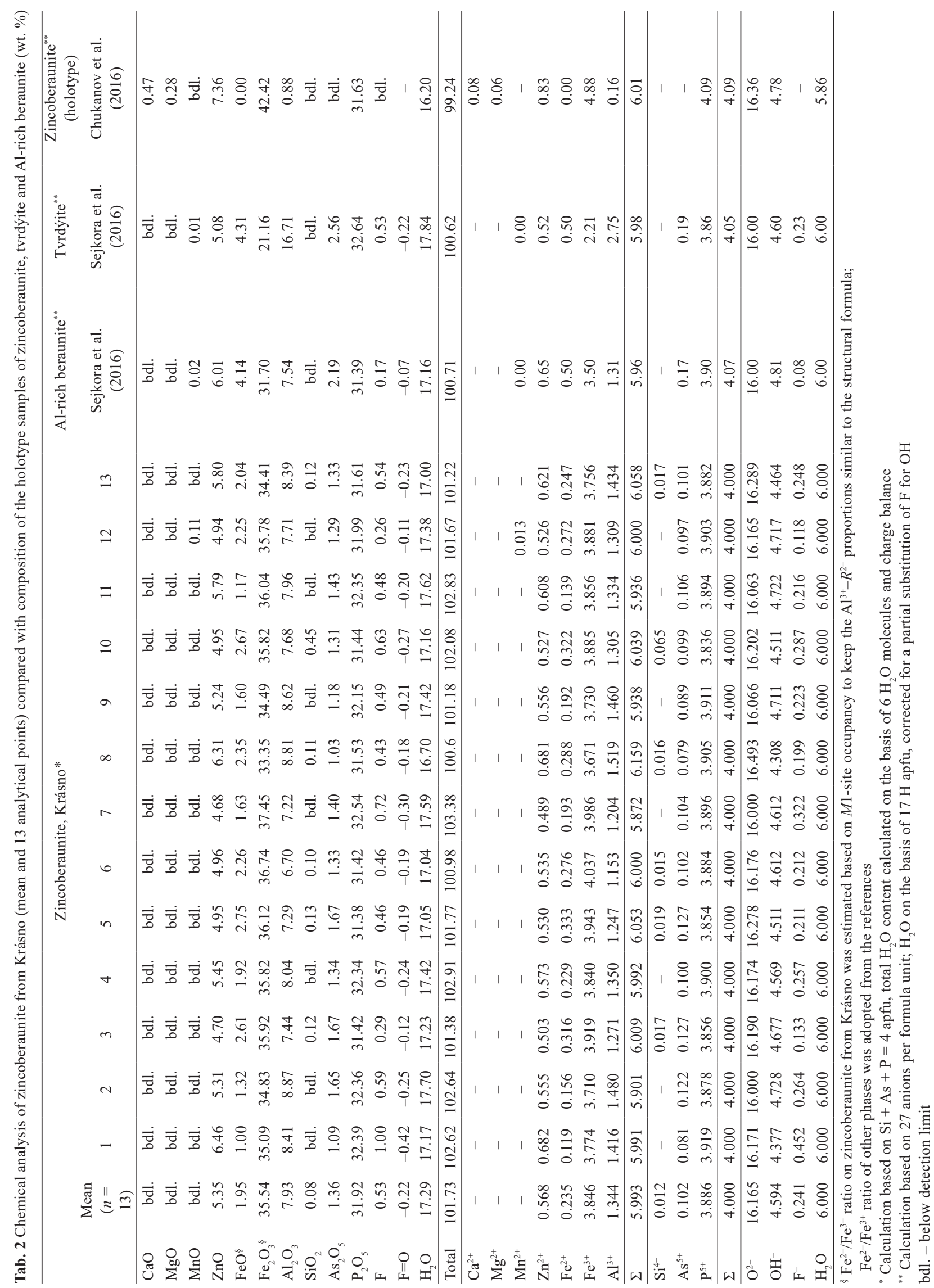




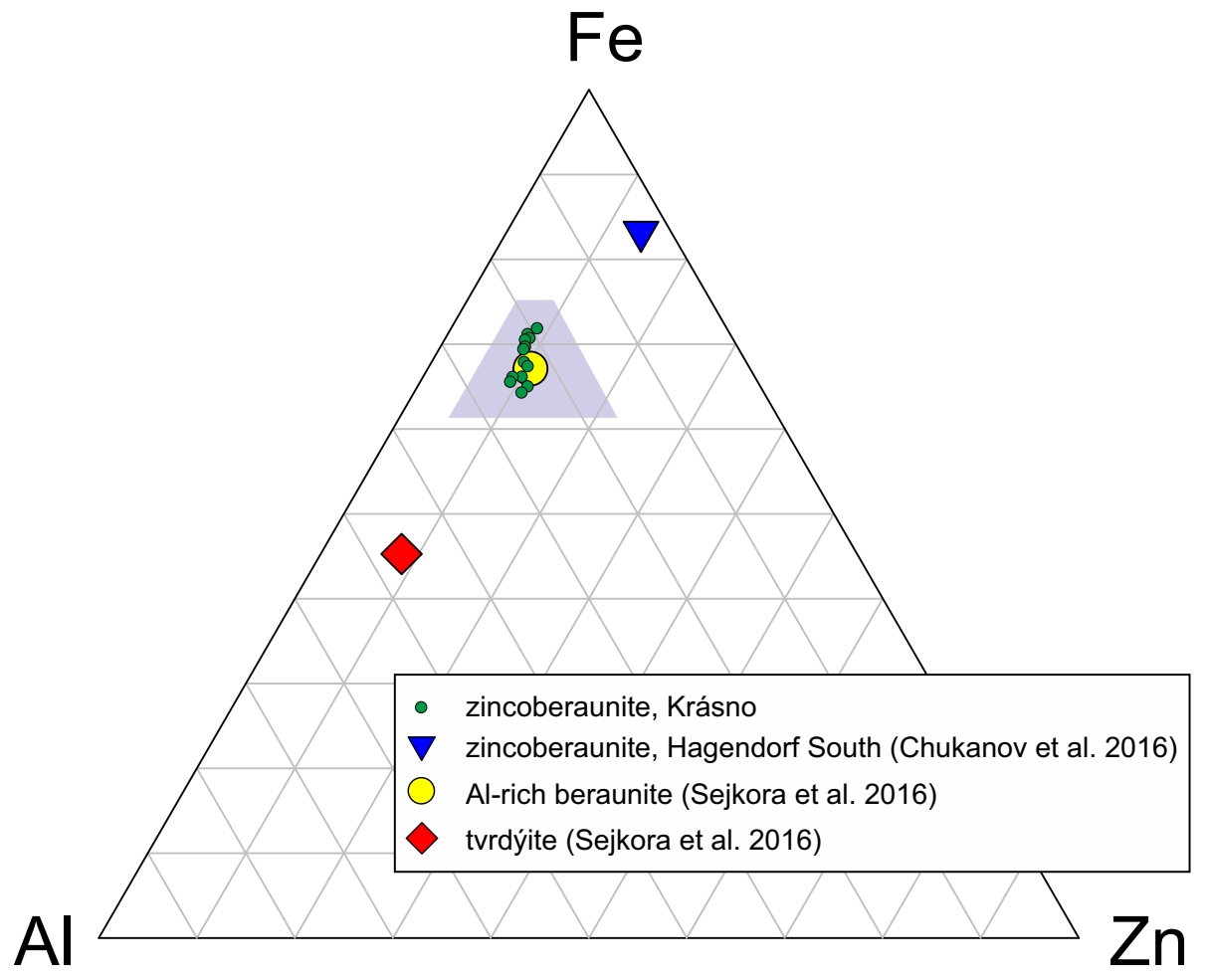

Fig. 3 Comparison of zincoberaunite from Krásno with holotype zincoberaunite (from Hagendorf South) and related mineral phases from Krásno in the Al- Fe-Zn ternary plot (apfu). Shaded field refers to the detail shown in Fig. 5.
$M 2-M 4$ sites, the ratio of $\mathrm{Al}^{3+}$ to $M e^{2+}$ in the $M 1$ position requires presence of divalent cations as follows:

$\left(\mathrm{Zn}_{0.57} \mathrm{Fe}_{0.24} \mathrm{Al}_{0.19}\right)_{\Sigma 1.00}\left(\mathrm{Fe}_{3.85} \mathrm{Al}_{1.15}\right)_{\Sigma 5.00}\left[\left(\mathrm{PO}_{4}\right)_{3.89}\left(\mathrm{AsO}_{4}\right)_{0.10}\right.$ $\left.\left(\mathrm{SiO}_{4}\right)_{0.01}\right]_{\Sigma 4.00}\left[(\mathrm{OH})_{4.59} \mathrm{~F}_{0.24} \mathrm{O}_{0.17}\right]_{\Sigma 5.00}\left(\mathrm{OH}_{2}\right)_{4.00} \cdot 2 \mathrm{H}_{2} \mathrm{O}$. Note that the empirical formula is a mean of 13 analyses. With respect to the chemical heterogeneity of the sample, zones with higher $\mathrm{Zn}$ content are expected to be closer to the structural formula.

Figure 3 shows a close relation between the $\mathrm{Zn}-\mathrm{Al}$ rich phases of the beraunite group from Krásno. As evident from Tab. 2, the mean $\mathrm{Zn}$ content in the studied sample of zincoberaunite is even lower than in the Al-rich beraunite described by Sejkora et al. (2016). The difference most probably consists in the way how $\mathrm{Zn}$ is distributed over the four metal cation sites: while in tvrdýite (and most likely also in associated Al-rich beraunite) $\mathrm{Zn}$ enters the $M 1, M 3$ and $M 4$ sites, in zincoberaunite it occupies predominantly the $M 1$ site. On the other hand, the Al content in the holotype specimen of zincoberaunite from Hagendorf South is significantly lower.

Tab. 3 Values of Pearson correlation coefficient for 13 point analyses of zincoberaunite

\begin{tabular}{lccccccc}
\hline & $\mathrm{Zn}$ & $\mathrm{Al}$ & $\mathrm{Fe}$ & $\mathrm{Si}$ & $\mathrm{As}$ & $\mathrm{P}$ & $\mathrm{F}$ \\
\hline $\mathrm{Zn}$ & 1 & - & - & - & - & - & - \\
$\mathrm{Al}$ & 0.70 & 1 & - & - & - & - & - \\
$\mathrm{Fe}$ & -0.69 & -0.90 & 1 & - & - & - & - \\
$\mathrm{Si}$ & -0.17 & -0.17 & 0.43 & 1 & - & - & - \\
$\mathrm{As}$ & -0.63 & -0.41 & 0.43 & 0.06 & 1 & - & - \\
$\mathrm{P}$ & 0.52 & 0.39 & -0.59 & -0.78 & -0.67 & 1 & - \\
$\mathrm{F}$ & 0.39 & 0.15 & -0.39 & -0.03 & -0.36 & 0.25 & 1 \\
\hline
\end{tabular}

The EPMA results show a strong negative $\mathrm{Al}-\mathrm{Fe}$ correlation as was also observed by Sejkora et al. (2016) both in tvrdýite and in Al-rich beraunite from the same locality (Fig. 4a). Contents of arsenic in the tetrahedral sites are apparently lower (Fig. 4b) than those reported by Sejkora et al. (2016) for Al-rich beraunite, but follow the same negative correlation between $\mathrm{P}$ and As. The positive correlation between $\mathrm{Al}$ and $\mathrm{F}$ is not evident; the $\mathrm{F}$ content in zincoberaunite is several times higher than that in Al-bearing beraunite (Fig. 4c). The biggest difference is in correlations of the pairs $\mathrm{Zn}-\mathrm{Fe}$ and $\mathrm{Zn}-\mathrm{Al}$ that have been excluded in the Al-beraunite-tvrdýite series (Sejkora et al. 2016) but become very significant in the case of individual zincoberaunite zones (Tab. 3). Individual zincoberaunite crystals exhibit chemical zonation manifested by increasing Fe and decreasing $\mathrm{Zn}$ and $\mathrm{Al}$ contents from cores to rims (Fig. 5).

\section{X-ray crystallography and crystal structure}

A single crystal extracted from the studied specimen was used for a single-crystal X-ray study on a Rigaku SuperNova diffractometer with mirror-monochromatized $\operatorname{Mo} K_{\alpha}$ radiation $(\lambda=$ $0.71073 \AA$ ) from a microfocus $\mathrm{X}$-ray source detected by an 
Atlas S2 CCD detector (Institute of Physics, Academy of Sciences of the Czech Republic). Crystallographic parameters and data collection details are given in Tab. 4. Integration of the data, including corrections for background, polarisation, Lorentz effects as well as absorption were carried out with the CrysAlis RED program (Rigaku 2018). The structure of zincoberaunite was solved independently from the previous structure determination (Chukanov et al. 2016) using the charge-flipping algorithm implemented in the SHELXT program (Sheldrick 2015) and subsequently refined by the least-squares algorithm with Jana2006 software (Petrríček et al. 2014) based on $F^{2}$. Nearly all atom sites were found by the solution, missing positions of the remaining $\mathrm{O}$ atoms, as well as positions of the $\mathrm{H}$ atoms, were subsequently located from difference-Fourier maps. All atoms, except hydrogens, were refined using anisotropic atomic displacement parameters $(A D P)$. Isotropic atomic displacement parameters of the $\mathrm{H}$ atoms were set to be $1.2 \times U_{\text {eq }}$ (equivalent $A D P$ ) of the corresponding donor $\mathrm{O}$ atoms. All cation sites were refined as mixed $(\mathrm{Zn}+\mathrm{Al}$ or $\mathrm{Fe}+\mathrm{Al})$ sites based on the EPMA data and crystal-chemical considerations. The refinement converged to the final $R(F)$ of $3.56 \%$ for 1906 unique observed reflections. Atom coordinates and displacement parameters are given in Tab. 5. The results of the bond-valence analysis using bond-valence parameters from Gagné and Hawthorne (2015) are listed in Tab. 6.

The general structure architecture is consistent with the previous structure determination by Chukanov et al. (2016) and in line with the general structural features of beraunite-type phosphate minerals (Moore and Kampf 1992). Nevertheless, the current study provided a better resolution of the hydrogen-bonding network due to bet-

Fig. 4 Plots of Al vs. total Fe (a), As vs. P (b) and $\mathrm{F}$ vs. $\mathrm{Al}$ (c) for zincoberaunite in comparison with data published for tvrdýite and Al-rich beraunite, all from the Huber open pit in Krásno.
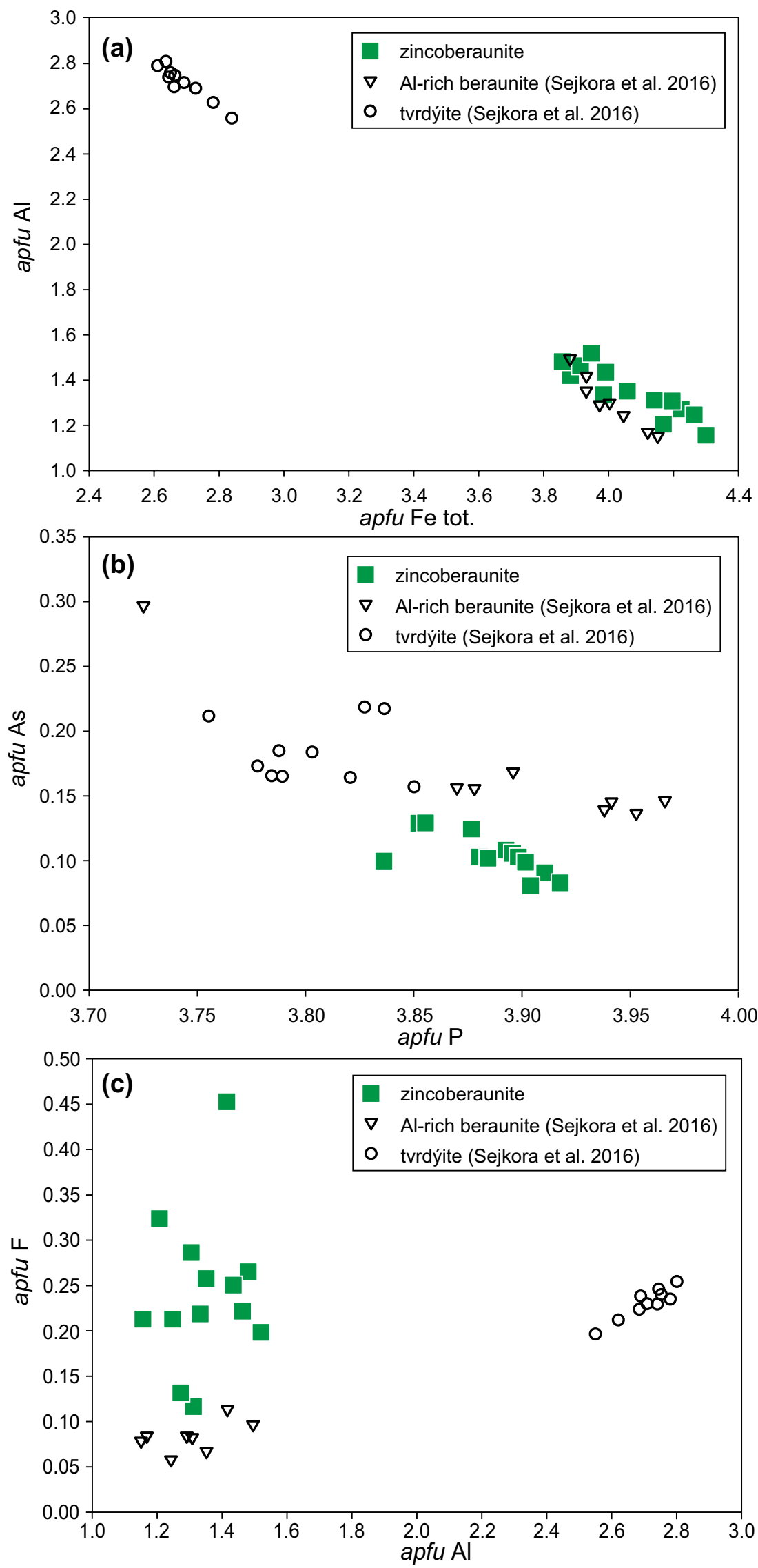


\section{$\mathrm{Fe}$}

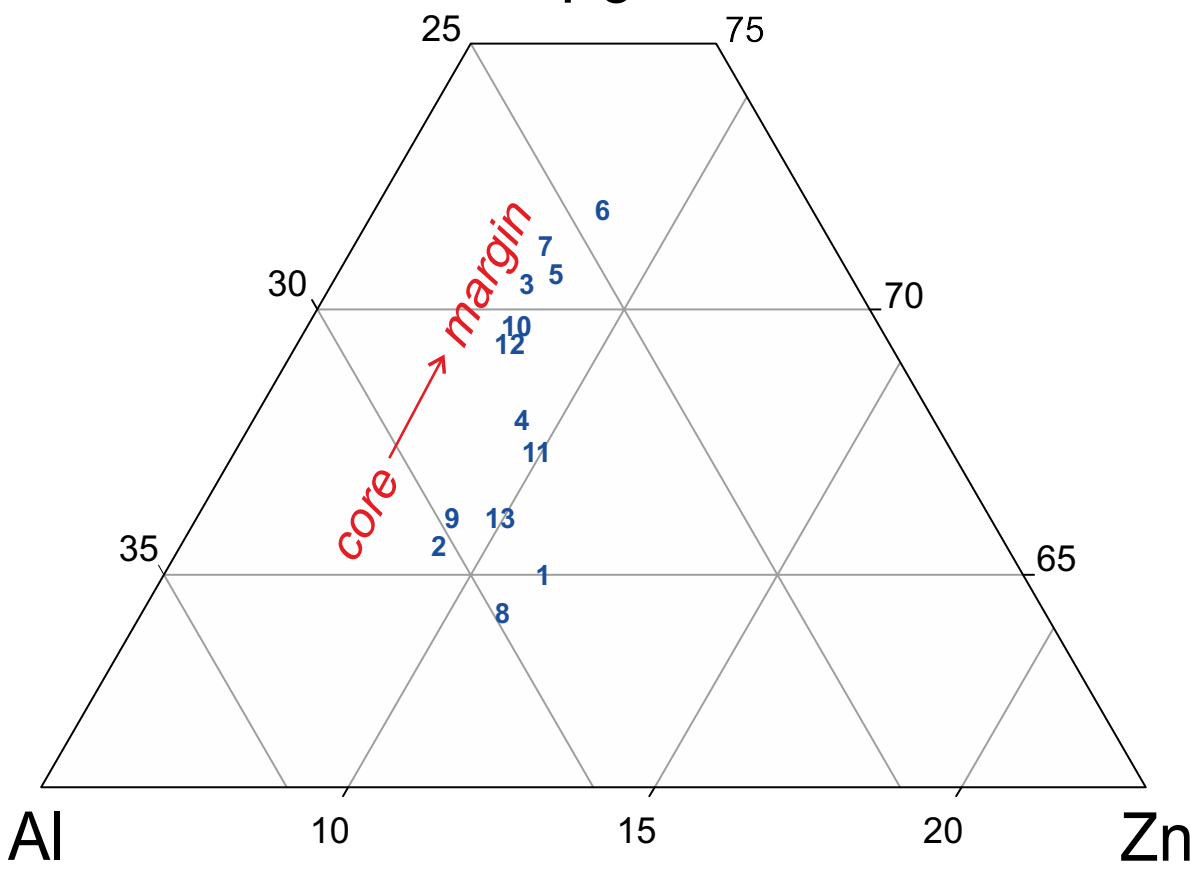

Tab. 4 Data collection and structure refinement details for zincoberaunite

\begin{tabular}{|c|c|}
\hline \multicolumn{2}{|l|}{ Crystal data } \\
\hline Structure formula & $\begin{array}{l}\left(\mathrm{Zn}_{0.81} \mathrm{Al}_{0.11}\right)(\mathrm{OH})_{2}\left(\mathrm{Fe}_{0.61} \mathrm{Al}_{0.39}\right)(\mathrm{OH})_{2}\left(\mathrm{H}_{2}{ }_{2}^{[3]} \mathrm{O}\right)_{2}\left(\mathrm{Fe}_{1.55} \mathrm{Al}_{0.48}\right) \\
\left(\mathrm{H}_{2}^{[3]} \mathrm{O}\right)_{2}\left(\mathrm{Fe}_{1.72} \mathrm{Al}_{0.28}\right)(\mathrm{OH})\left(\mathrm{PO}_{4}\right)_{3.83}\left(\mathrm{AsO}_{4}\right)_{0.17}\left(\mathrm{H}_{2}^{[4]} \mathrm{O}\right)_{2}\end{array}$ \\
\hline Crystal system & monoclinic \\
\hline Space group & $C 2 / m$ \\
\hline Unit-cell parameters: $a, b, c[\AA], \beta\left[^{\circ}\right]$ & $20.3340(19), 5.1507(3), 19.1361(15), 93.568(8)$ \\
\hline Unit-cell volume $\left[\AA^{3}\right]$ & $2001.3(3)$ \\
\hline$Z$ & 4 \\
\hline Calculated density $\left[\mathrm{g} / \mathrm{cm}^{3}\right]$ & 2.938 \\
\hline Crystal size $[\mathrm{mm}]$ & $0.072 \times 0.016 \times 0.009$ \\
\hline$F_{000}$ & 1754 \\
\hline \multicolumn{2}{|l|}{ Data collection } \\
\hline Diffractometer & Rigaku SuperNova with Atlas S2 detector \\
\hline Temperature $[\mathrm{K}]$ & 297 \\
\hline Radiation, wavelength $[\AA]$ & $\operatorname{Mo} K_{\alpha}, 0.71073(50 \mathrm{kV}, 30 \mathrm{~mA})$ \\
\hline$\theta$ range for data collection $\left[{ }^{\circ}\right]$ & $2.98-28.56$ \\
\hline Limiting Miller indices & $h=-27 \rightarrow 26, k=-6 \rightarrow 6, l=-25 \rightarrow 4$ \\
\hline Total reflections collected & 13326 \\
\hline Unique reflections & 2367 \\
\hline Unique observed reflections, criterion & $1906,[I>3 \sigma(I)]$ \\
\hline Absorption coefficient $\left[\mathrm{mm}^{-1}\right]$, type & 4.48; multi-scan \\
\hline$T_{\min } / T_{\max }$ & $0.813 / 1$ \\
\hline$R_{\text {int }}$ & 0.047 \\
\hline Structure refinement by Jana2006 & Full-matrix least-squares on $F^{2}$ \\
\hline $\begin{array}{l}\text { Number of refined parameters, restraints, } \\
\text { constraints }\end{array}$ & $202,10,57$ \\
\hline$R, w R$ (obs) & $0.0356,0.0452$ \\
\hline$R, w R($ all $)$ & $0.0576,0.0491$ \\
\hline Goodness of fit (obs, all) & $1.60,1.54$ \\
\hline Weighting scheme, weights & $\sigma, w=1 /\left(\sigma^{2}(I)+0.0004 I^{2}\right)$ \\
\hline Largest diffraction peak and hole $\left[\mathrm{e}^{-} / \AA^{3}\right]$ & $1.18 ; 1.11$ \\
\hline
\end{tabular}

Fig. 5 Ternary plot of Al-Fe -Zn (apfu) showing the zoning of zincoberaunite crystals; the field extent is shown in the plot in Fig. 3; numbers of points correspond to Tab. 2.

ter quality of diffraction data. The key feature of the zincoberaunite structure is a trimer of face-sharing octahedra centred by $\mathrm{Fe} 4-M 1-\mathrm{Fe} 4$, forming the core of the so-called $h$-cluster of Moore (1970). The trimers are connected by corner-sharing to the P1- and P2-centred tetrahedra and to pairs of cornershared Fe3-centred octahedra to form heteropolyhedral slabs coplanar with (100). These slabs are interlinked via corner-sharing with $(M 2) \mathrm{O}_{2}(\mathrm{OH})_{2}\left(\mathrm{H}_{2} \mathrm{O}\right)_{2}$ octahedra to form a 3D framework containing large ten-sided channels along [010].

The water molecules represented by the $\mathrm{O} 13$ and $\mathrm{O} 14$ atoms are located in the channels and are attached by the weak $\mathrm{H}$ bonds to the framework (Fig. 6). The structural formula obtained from the refinement, based on refined site occupancies and bond-valence considerations is $\left(\mathrm{Zn}_{0.81} \mathrm{Al}_{0.19}\right)(\mathrm{OH})_{2}\left(\mathrm{Fe}_{0.61} \mathrm{Al}_{0.39}\right)$ $(\mathrm{OH})_{2}\left(\mathrm{H}_{2}{ }^{[3]} \mathrm{O}\right)_{2}\left(\mathrm{Fe}_{1.52} \mathrm{Al}_{0.48}\right)$ $\left(\mathrm{H}_{2}{ }^{[3]} \mathrm{O}\right)_{2}\left(\mathrm{Fe}_{1.72} \mathrm{Al}_{0.28}\right)(\mathrm{OH})$ $\left(\mathrm{PO}_{4}\right)_{3.83}\left(\mathrm{AsO}_{4}\right)_{0.17}\left(\mathrm{H}_{2}{ }^{[4]} \mathrm{O}\right)_{2}$, 
$Z=4$. Although this formula is not fully electroneutral (surplus of 0.19 positive charges), we are not able to elucidate the exact charge-balancing mechanism, which is most likely based on an $\mathrm{OH} \leftrightarrow \mathrm{O}$ substitution. However, we are convinced that the formula can be considered as reliable. The site occupancies should be viewed as the "best proxies", due to the similar scattering power of the substituting elements $\mathrm{Zn}$ and $\mathrm{Fe}$, and the fact that $\mathrm{Al}$ is most likely randomly distributed over the all metalcation sites.

In the crystal structure of zincoberaunite, there are three distinct $\mathrm{H}_{2} \mathrm{O}$ molecules, in addition to five $\mathrm{OH}$ groups. These $\mathrm{H}_{2} \mathrm{O}$ groups play a different role in the structure bonding. One of the classifications or typology of the molecular $\mathrm{H}_{2} \mathrm{O}$ in the structures of inorganic solids and minerals is based on their role in the structure bonding (Hawthorne 1994; Hawthorne and Schindler 2008; Hawthorne 2015). Particular types of $\mathrm{H}_{2} \mathrm{O}$ can be distinguished based on the coordination number of $\mathrm{O}$ atoms in these $\mathrm{H}_{2} \mathrm{O}$ groups: there are transformer, non-transformer, and inverse transformer $\mathrm{H}_{2} \mathrm{O}$ groups with [3], [4], and [5]-fold coordinated $\mathrm{O}$ atoms, respectively. In general, the role of all types of molecular $\mathrm{H}_{2} \mathrm{O}$ in the structure is to transfer the bond-valence from cations (corresponding to Lewis acids) to anions (corresponding to Lewis bases). This action keeps the structure, in particular of hydrates of inorganic oxysalts, together, as the strengths of these components are equal or similarly matching, thus following the valence-matching principle of the bond-valence model (Brown 2009; Hawthorne 2012, 2015).

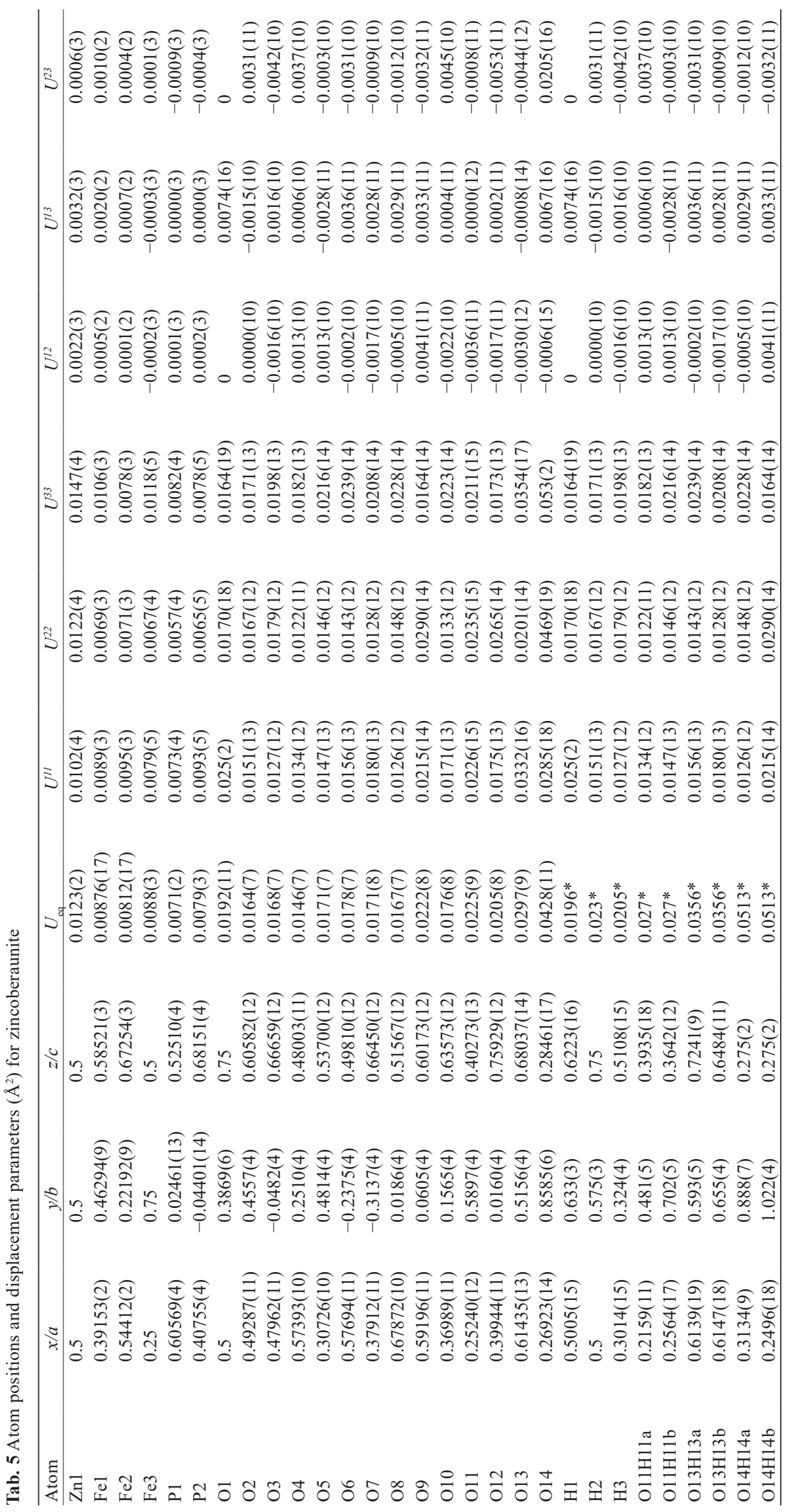


Tab. 6 Bond-valence analysis (valence units, $v u$ ) for zincoberaunite

\begin{tabular}{|c|c|c|c|c|c|c|c|c|c|c|c|c|c|c|c|}
\hline Atom & $\mathrm{O} 1$ & $\mathrm{O} 2$ & $\mathrm{O} 3$ & $\mathrm{O} 4$ & O5 & O6 & $\mathrm{O} 7$ & $\mathrm{O} 8$ & O9 & $\mathrm{O} 10$ & O11 & $\mathrm{O} 12$ & $\mathrm{O} 13$ & $\mathrm{O} 14$ & $\sum$ \\
\hline $\mathrm{Zn} 1$ & & $0.38 \times 2 \rightarrow$ & & $0.40 \times 2 \rightarrow$ & & $0.36 \times 2 \rightarrow$ & & & & & & & & & 2.28 \\
\hline $\mathrm{Fe} 1$ & & 0.41 & & 0.40 & 0.67 & 0.37 & 0.60 & & & 0.63 & & & & & 3.08 \\
\hline $\mathrm{Fe} 2$ & 0.52 & 0.48 & 0.62 & & & & & & 0.62 & & & 0.50 & 0.39 & & 3.13 \\
\hline $\mathrm{Fe} 3$ & & & & & $0.58 \times 2 \rightarrow$ & & & $0.58 \times 2 \rightarrow$ & & & $0.41 \times 2 \rightarrow$ & & & & 3.14 \\
\hline$T 1$ & & & & 1.19 & & 1.25 & & 1.38 & 1.34 & & & & & & 5.16 \\
\hline$T 2$ & & & 1.35 & & & & 1.28 & & & 1.29 & & 1.26 & & & 5.18 \\
\hline H1 & & 0.88 & 0.10 & & & & & & & & & & & & 0.98 \\
\hline $\mathrm{H} 2$ & 0.89 & & 0.02 & & & & & & & & & & & & 0.91 \\
\hline $\mathrm{H} 3$ & & & & & 0.91 & & & 0.10 & & & & & & & 1.01 \\
\hline O11H11a & & & & & & & & & & 0.09 & 0.96 & & & & 1.05 \\
\hline $\mathrm{O} 11 \mathrm{H} 11 \mathrm{~b}$ & & & & & & & & & & & 0.94 & & & 0.14 & 1.08 \\
\hline O13H13a & & & & & & & 0.05 & & & & & & 0.98 & & 1.04 \\
\hline $\mathrm{O} 13 \mathrm{H} 13 \mathrm{~b}$ & & & & & & & & & 0.04 & & & & 0.94 & & 0.98 \\
\hline $\mathrm{O} 14 \mathrm{H} 14 \mathrm{a}$ & & & & & & & & & & & & 0.11 & & 0.95 & 1.06 \\
\hline $\mathrm{O} 14 \mathrm{H} 14 \mathrm{~b}$ & & & & & & & & & & & & & & 1.00 & 1.00 \\
\hline$\sum$ & 1.41 & 2.15 & 2.09 & 1.99 & 2.16 & 1.98 & 1.93 & 2.06 & 2.00 & 2.01 & 2.31 & 1.87 & 2.31 & 2.09 & \\
\hline
\end{tabular}

The three symmetrically distinct $\mathrm{H}_{2} \mathrm{O}$ molecules in the structure of zincoberaunite actually represent two distinct groups. While O11(Wa) and O13(Wa) are socalled transformer $\mathrm{H}_{2} \mathrm{O}$ groups with [3]-coordinated $\mathrm{O}$ atoms, O14(Wa), which is localised in the channels running parallel to $b$, is a non-transformer group with a [4]-coordinated $\mathrm{O}$ atom (Fig. 7). In addition, three $\mathrm{OH}$ groups help to propagate the bond-valence within the framework.

\section{Raman spectroscopy}

Raman spectroscopy of zincoberaunite was undertaken on the uncoated polished epoxy mount, by means of Horiba LabRAM HR Evolution spectrometer (Masaryk University Brno). This dispersive, edge-filter-based system, operating in $180^{\circ}$ backscattered geometry, was equipped with Olympus BX 41 optical microscope, a diffraction grating with 600 grooves per millimetre, and a Peltier-cooled, Si-based charge-coupled device (CCD) detector. The $633 \mathrm{~nm} \mathrm{He}-\mathrm{Ne}$ laser ( $3 \mathrm{~mW}$ at the sample surface) and $50 \times$ objective were selected for spectra acquisition. Higher laser powers caused damage of the analysed spot. Wavenumber calibration was done using the Rayleigh line and low-pressure Ne-lamp discharge emissions. The wavenumber accuracy was $<0.5 \mathrm{~cm}^{-1}$, and the spectral resolution is $\sim 2 \mathrm{~cm}^{-1}$ in the range $75-4000 \mathrm{~cm}^{-1}$. Band fitting was done after appropriate background correction, assuming combined Lorentzian-Gaussian band shapes (Voight function) using PeakFit (Jandel Scientific Software).

For holotype zincoberaunite, only the infrared absorption

Fig. 6 The crystal structure of zincoberaunite from Krásno viewed down the two-fold axis with displayed $\mathrm{H}$ -bonds; unit-cell edges are outlined in red colour. 


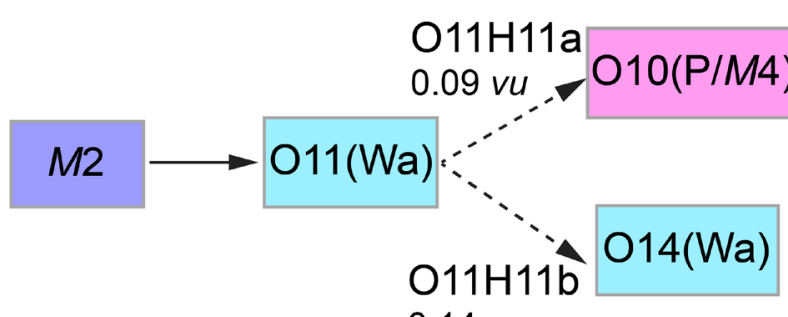

$0.14 v u$
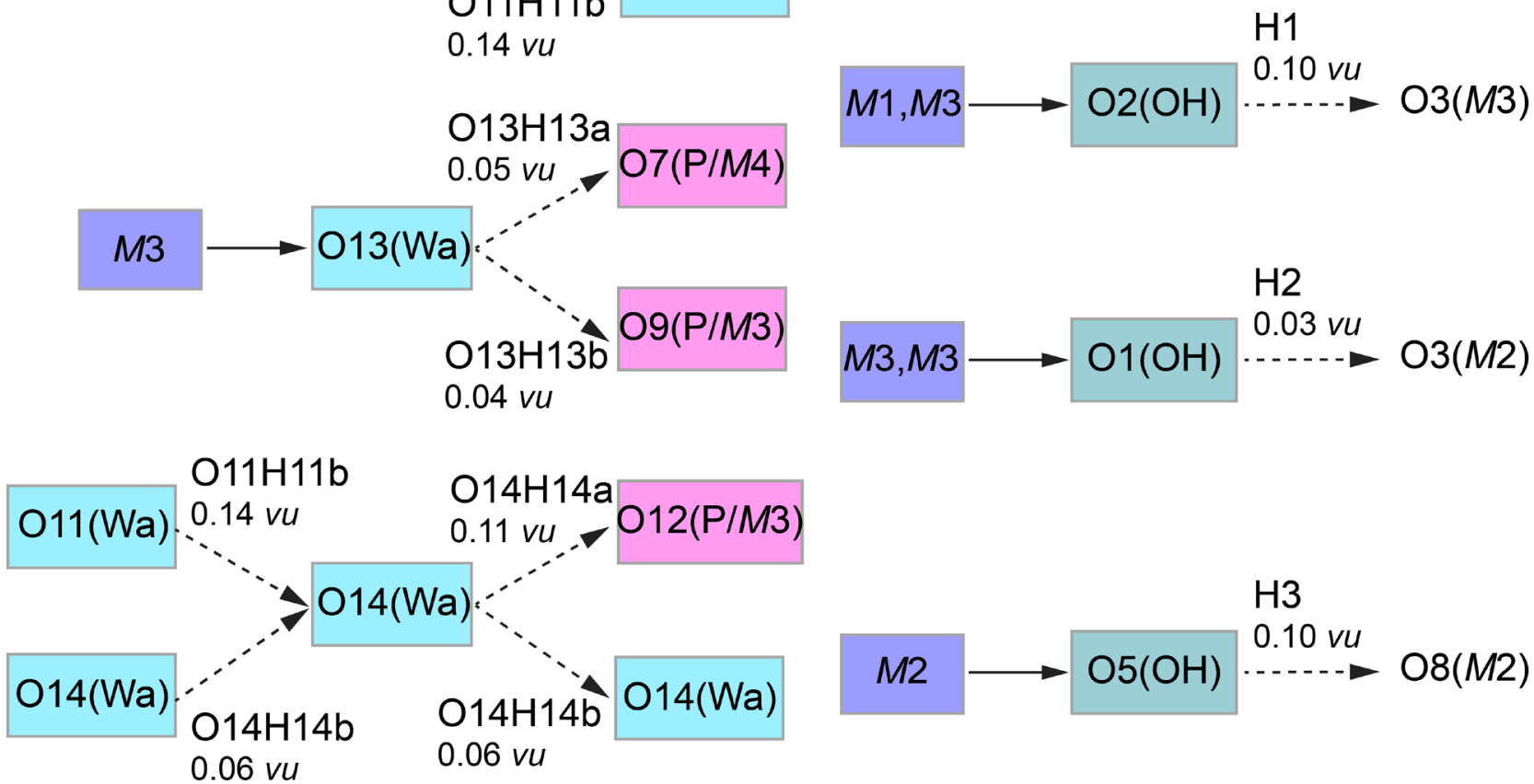

Fig. 7 Hydrogen bonding in the structure of zincoberaunite. $M X(X=1-3)=$ octahedrally coordinated metal cations, $\mathrm{Wa}=\mathrm{H}_{2} \mathrm{O}$ molecule, $\mathrm{OH}=$ hydroxyl group; bond-strengths are given in valence units (vu).

spectrum was reported in the original description (Chukanov et al. 2016); Raman spectroscopy data have not been published so far. Comparison with Raman spectra of related minerals of the beraunite group shows their mutual similarity, but also distinct minor differences (Fig. 8).

Following interpretations are based on the vibrational spectroscopic study of brownish beraunite performed by Frost et al. (2014). In the high-energy region (Fig. 9), the vibrational band at $3563 \mathrm{~cm}^{-1}$ can be assigned to the stretching vibration of the $\mathrm{OH}$ ions. Bands at 3418 and $3261 \mathrm{~cm}^{-1}$ are attributed to stretching vibrations of symmetrically distinct hydrogen-bonded water molecules (Sejkora et al. 2016). The corresponding $\mathrm{O}-\mathrm{H} \cdots \mathrm{O}$ hydrogen bond lengths calculated using the regression curve of Libowitzky (1999) are 2.81 and $2.73 \AA$; both values are in good agreement with the hydrogen bond donor and acceptor distances in the Tab. 7.

In the range below $1300 \mathrm{~cm}^{-1}$ (Fig. 10), the strongest bands at 999 and $1044 \mathrm{~cm}^{-1}$ are attributed to the $v_{1}$ symmetric stretching mode of $\mathrm{PO}_{4}^{3-}$ and the bands at 1096, 1132 and $1156 \mathrm{~cm}^{-1}$ are assigned to the $v_{3}$ antisymmetric stretching vibrations of $\mathrm{PO}_{4}{ }^{3-}$ units (Frost et al. 2014; Sejkora et al. 2016). The weak bands at 935 and $873 \mathrm{~cm}^{-1}$ were not reported in the beraunite pattern of Frost et al. (2014) but they are present in the Raman spectrum of tvrdýite. Sejkora et al. (2016) interpreted them as a manifestation of the $\delta M-\mathrm{OH}$ bending vibrations or $\mathrm{H}_{2} \mathrm{O} / \mathrm{OH}$ libration modes. A peak equivalent to the $935 \mathrm{~cm}^{-1}$ band occurs in the spectrum of beraunite sample R060464 in the Rruff Project website (Rruff Project 2019; pattern d in the Fig. 8); in phosphosiderite (Scholz et al. 2013) this band is assigned to a $\mathrm{P}-\mathrm{O}$ stretching vibration of protonated phosphate units. In the Raman spectrum of tvrdýite, unless there are other influences, this could be due to the significant presence of components other than iron in the structure $\left(\mathrm{Al}, \mathrm{Zn}\right.$, or $\mathrm{AsO}_{4}$ group). The series of Raman bands in the ranges of 681-569 $\mathrm{cm}^{-1}$ and $486-397 \mathrm{~cm}^{-1}$ are related to $v_{4}(\delta)$ and $v_{2}(\delta)$ bending vibrations of $\mathrm{PO}_{4}$ groups, respectively. The bands at 364 and $317 \mathrm{~cm}^{-1}$ are attributed to the $\mathrm{M}-\mathrm{O}$ stretching vibrations. The series of overlapping bands at 247, 208, 184, 136, 117 and $86 \mathrm{~cm}^{-1}$ are due to external or lattice vibrations (Frost et al. 2014; Sejkora et al. 2016).

\section{Note on origin}

According to Sejkora et al. (2006), the zone of occurrences of phosphate mineralizations in the Huber open 


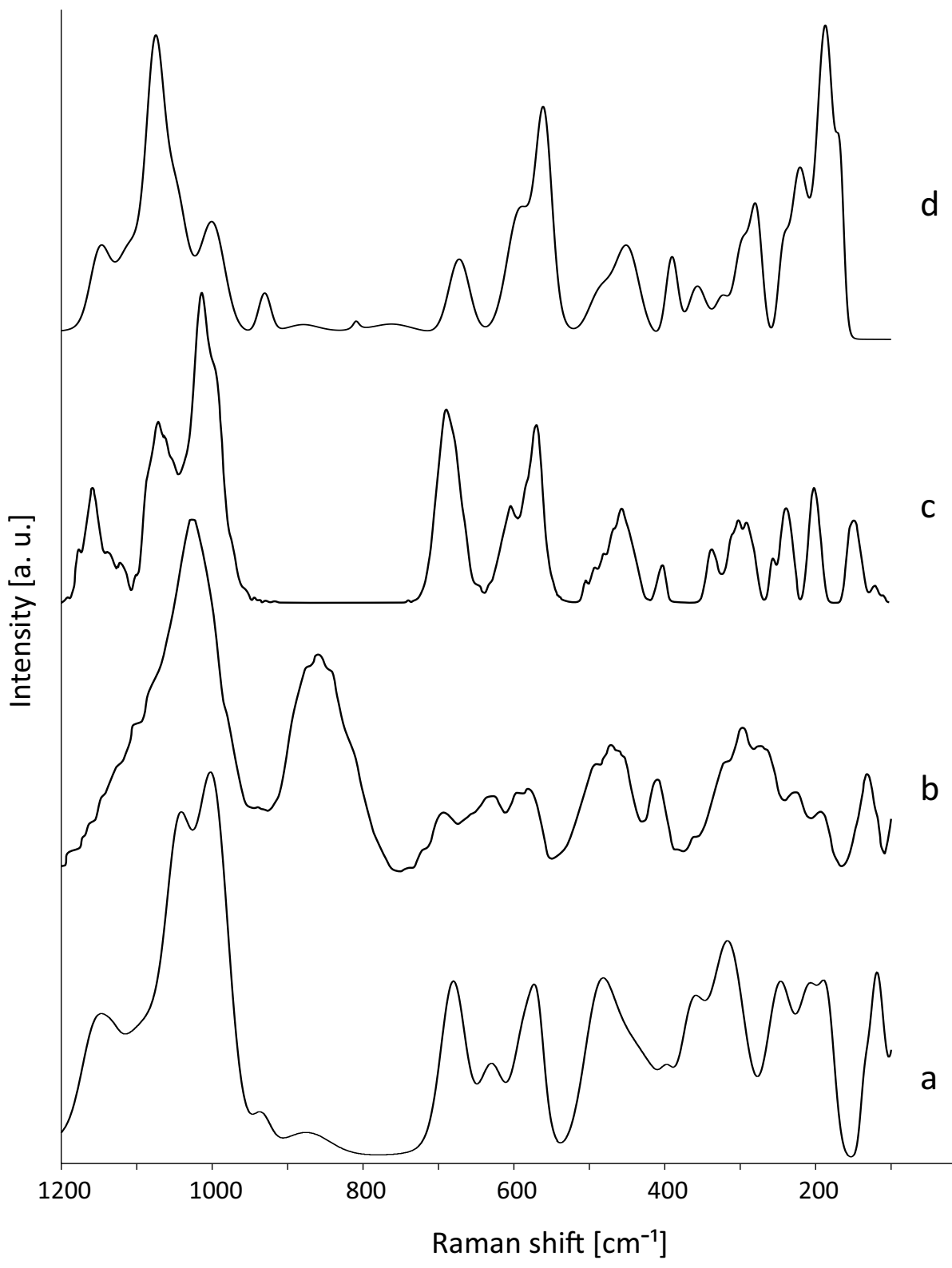

Fig. 8 Comparison of the Raman spectra of zincoberaunite from Krásno and related minerals: a - zincoberaunite, Krásno, adjusted and smoothed; b - tvrdýite, Krásno (Sejkora et al. 2016), scale adjusted; c - beraunite, Boca Rica, Minas Gerais, Brazil (Frost et al. 2014), scale adjusted; $\mathbf{d}$ - beraunite, York mine, Polk County, Arkansas, USA (Beraunite R060464, Rruff Project 2019), processed from the original dataset; both $\mathrm{c}$ and $\mathrm{d}$ beraunite samples have a brownish colour and their relation to eleonorite (later described member of the beraunite group) is not clear. pit is exposed c. 20-40 m below the contact of the upper part of the greisenized stock with host gneisses, i.e.

Tab. 7 Geometrical characteristics for hydrogen bonds (in $\AA$ and ${ }^{\circ}$ ) in the structure of zincoberaunite

\begin{tabular}{|c|c|c|c|c|}
\hline$D-\mathrm{H} \cdots A$ & $D-\mathrm{H}(\AA)$ & $\mathrm{H} \cdots A(\AA)$ & $D \cdots A(\AA)$ & $D-\mathrm{H}^{\prime} \cdots A\left(^{\circ}\right)$ \\
\hline $\mathrm{O} 2-\mathrm{H} 1 \cdots \mathrm{O} 3^{\mathrm{ii}}$ & $0.98(2)$ & $1.91(2)$ & $2.828(3)$ & $155(4)$ \\
\hline $\mathrm{O} 1-\mathrm{H} 2 \cdots \mathrm{O} 3^{\mathrm{ii}}$ & $0.97(2)$ & $2.53(1)$ & $3.332(3)$ & $140(2)$ \\
\hline $\mathrm{O} 5-\mathrm{H} 3 \cdots \mathrm{O} 8^{\mathrm{iii}}$ & $0.96(2)$ & $1.89(2)$ & $2.787(3)$ & $155(3)$ \\
\hline O11-O11H11a $\cdots$ O10 & $0.93(2)$ & $1.94(2)$ & $2.848(3)$ & $164(2)$ \\
\hline $\mathrm{O} 11-\mathrm{O} 11 \mathrm{H} 11 \mathrm{~b} \cdots \mathrm{O} 14$ & $0.95(2)$ & $1.76(2)$ & $2.690(4)$ & $169(3)$ \\
\hline O13-O13H13a $\cdots{ }^{-O} 7^{x v}$ & $0.93(2)$ & $2.18(2)$ & $3.090(3)$ & $167(2)$ \\
\hline $\mathrm{O} 13-\mathrm{O} 13 \mathrm{H} 13 \mathrm{~b} \cdots \mathrm{O}^{\mathrm{ii}}$ & $0.95(2)$ & $2.31(2)$ & $3.204(3)$ & $158(2)$ \\
\hline O14-O14H14a $\cdots$ O12 ${ }^{\mathrm{xi}}$ & $0.94(2)$ & $1.86(2)$ & $2.798(3)$ & $174(3)$ \\
\hline $\mathrm{O} 14-\mathrm{O} 14 \mathrm{H} 14 \mathrm{~b} \cdots \mathrm{O} 14^{\mathrm{xiii}}$ & $0.94(3)$ & $2.10(3)$ & $2.978(4)$ & $155(3)$ \\
\hline
\end{tabular}

Symmetry codes: (ii) $\mathrm{x}, \mathrm{y}+1, \mathrm{z}$; (iii) $-\mathrm{x}+1,-\mathrm{y},-\mathrm{z}+1$; (viii) $-\mathrm{x}+1 / 2,-\mathrm{y}+1 / 2,-\mathrm{z}+1$; (xiii) $-\mathrm{x}+1 / 2, \mathrm{y}+1 / 2$, $-\mathrm{z}+1 / 2$; (xv) $-\mathrm{x}+1, \mathrm{y}+1,-\mathrm{z}+3 / 2$; (xvi) $\mathrm{x},-\mathrm{y}+1, \mathrm{z}-1 / 2$. D - donor, $\mathrm{A}-$ acceptor approximately $50-80 \mathrm{~m}$ below the original land surface prior to mining.

At the late stages of hydrothermal activity, the primary phosphates (including fluorapatite and triplite) underwent metasomatic replacement (Sejkora et al. 2006). Subsequently, corrosion cavities appeared replacing in-situ fluorapatitetriplite aggregates and a part of the dissolved elements released from primary phosphates was transferred to hydrothermal solutions and later on precipitated as secondary minerals in quartz 


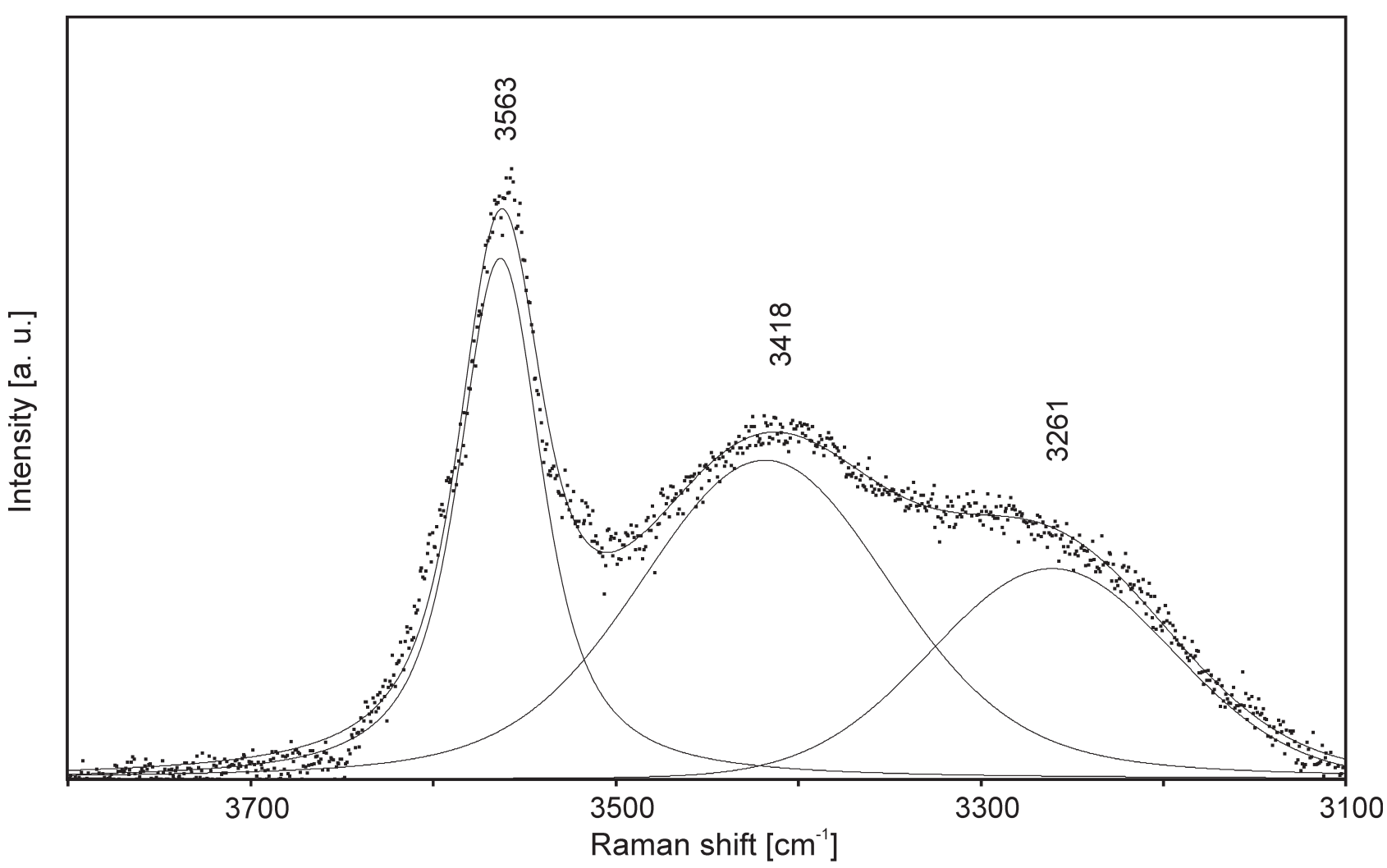

Fig. 9 Raman spectrum of zincoberaunite from Krásno in the region $3800-3100 \mathrm{~cm}^{-1}$.

cavities. The typical assemblage of the corrosion cavities comprises phosphates such as kunatite (Mills et al. 2008), plimerite (Sejkora et al. 2011), iangreyite (Mills et al. 2011) or krásnoite (Mills et al. 2012). According to observations of the limited number of specimens available, it seems that beraunite-related minerals (tvrdýite, zincoberaunite) belong to remobilised secondary phases that typically occur in quartz cavities without any other associated minerals.

The high Al contents in the studied Al-Zn-rich beraunite-related minerals from Krásno are in line with abundant distribution of kaolinite-group minerals (most of them unidentified; part of them are ascribed to dickite) in the gangue cavities (Sejkora et al. 2006). This suggests a high activity of $\mathrm{Al}^{3+}$ in the parental aqueous solutions, in turn implying low $\mathrm{pH}$ conditions (caused by oxidation of the abundant arsenopyrite). These solutions underwent transport through the body of greisenized rocks with abundant arsenopyrite, chalcopyrite and sphalerite; therefore, they became enriched in $\mathrm{As}, \mathrm{Fe}, \mathrm{Cu}$ and $\mathrm{Zn}$. The solutions caused precipitation of various $\mathrm{Fe}-\mathrm{Zn}-\mathrm{Cu}$ arsenates in quartz cavities (Vrtiška et al. 2018; Sejkora et al. 2019a and references therein) or they interacted with primary phosphates during transport; this enrichment in $\mathrm{PO}_{4}^{3-}$ resulted in later crystallisation of secondary phosphate minerals such as zincoberaunite. The observed chemical zoning of the studied zincoberaunite (rimward decrease in $\mathrm{Al}$ ) indicates gradual evolution of the solutions towards more alkaline $\mathrm{pH}$ during zincoberaunite crystallisation.

\section{Conclusions}

The phosphates of the beraunite group complete the rich and rather variable association of late hydrothermal minerals in the Krásno-Horní Slavkov ore district. The related $\mathrm{Zn}$-Al-rich members of the beraunite group found in the now abandoned Huber open pit show considerable compositional and crystalochemical variability, in particular in the occupancy of individual structural positions. In this paper, attention is paid to aluminium-rich zincoberaunite, which is characterised by selective zinc accumulation at the $M 1$ site. Contrary to expectations, however, trivalent aluminium also enters this position which is theoretically "reserved" for divalent cations; the role of the di- and trivalent iron is not entirely clear.

The studied zincoberaunite differs from the previously described tvrdýite from the same locality. In the latter, zinc is contained in positions $M 1, M 3$ and $M 4$ without statistical predominance. Bulk Zn content in tvrdýite and associated Al-rich beraunite approaches, or in some cases even exceeds, that in zincoberaunite. 


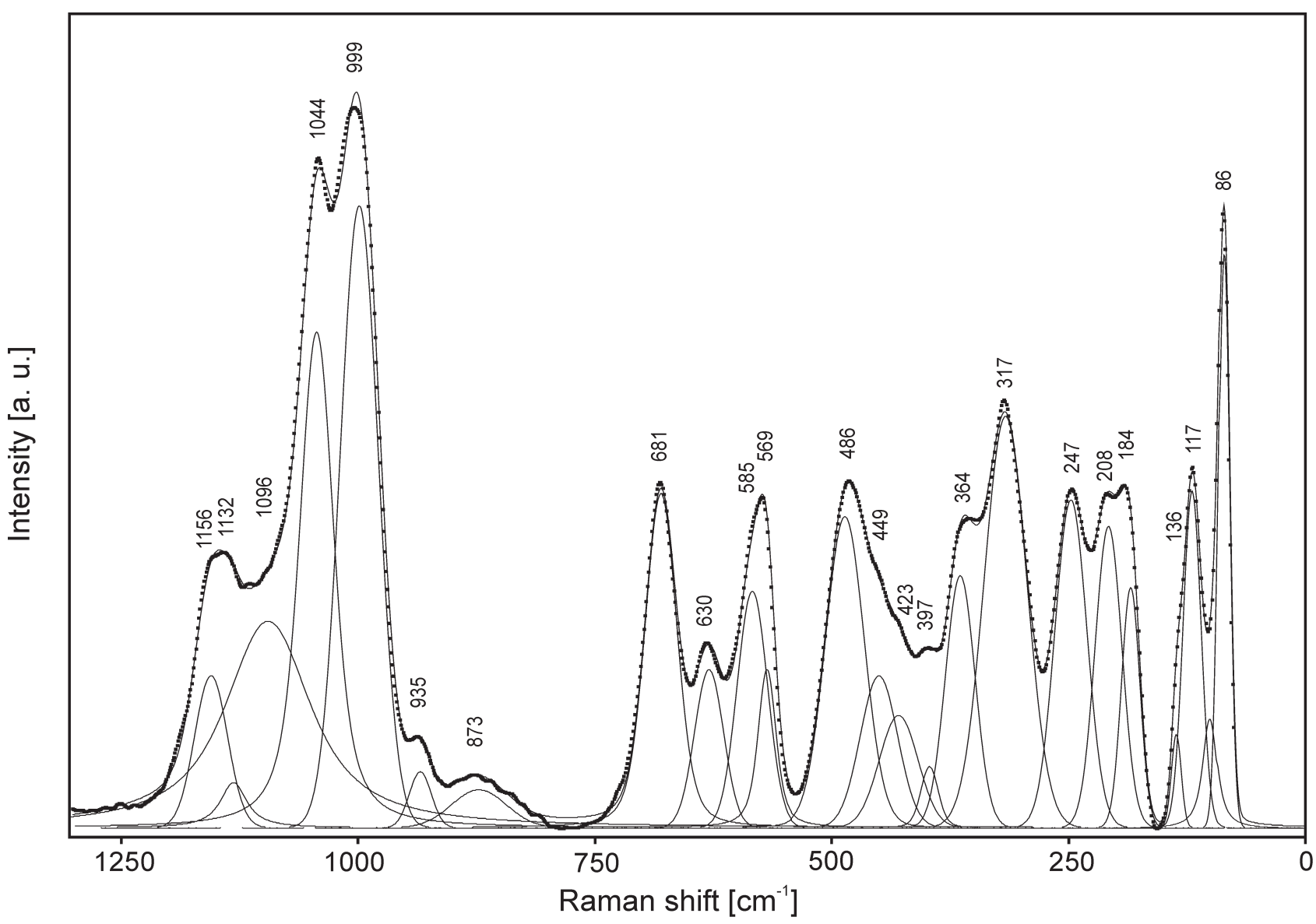

Fig. 10 Raman spectrum of zincoberaunite from Krásno in the region 1300-75 $\mathrm{cm}^{-1}$.

Acknowledgements. The editor-in-chief Vojtěch Janoušek, handling editor Jan Cempírek as well as both reviewers, Uwe Kolitsch and Jiři Sejkora, are acknowledged for valuable comments and suggestions that improved the manuscript. Special thanks go to Milan Gebouský, who kindly provided the sample. This work was financially supported by the Grant Agency of Masaryk University, Subprogramme Category A, Project MUNI/A/1387/2018, and the Czech Science Foundation, Project GACR 1709161S.

Electronic supplementary material. Supplementary original crystallographic information file (cif) for the studied zincoberaunite crystal is available online at the Journal web site (http://dx.doi.org/10.3190/jgeosci.296).

\section{References}

BERAN P (1995) Mineralogy and petrology of the Sn-W deposit Krásno near Horní Slavkov. Bull mineral-petrolog Odd Nár Muz (Praha) 3: 108-124 (in Czech)

Beran P, SejKora J (2006) The Krásno Sn-W ore district near Horní Slavkov: mining history, topographical, geological and mineralogical characteristics. J Czech Geol Soc 51: 3-42

Breithaupt A (1840) Beraunit, ein neues Glied der PhyllitOrdnung. J Prakt Chem 20: 66-67

Breithaupt A (1841) Vollständiges Handbuch der Mineralogie, Zweiter Band, I. Phyllites. Anhang 5. Beraunit. Arnoldische Buchhandlung, Dresden \& Leipzig, pp 156

BROWN ID (2009) Recent developments in the methods of the bond valence model. Chem Rev 109: 6858-6919

Chukanov NV, Pekov IV, Grey IE, Price JR, Britvin SN, Krzhizhanovskaya MG, KampF AR, DÜNKel B, Keck E, Belakovskiy DI, MacRae CM (2016) Zincoberaunite, $\mathrm{ZnFe}_{5}^{3+}\left(\mathrm{PO}_{4}\right)_{4}(\mathrm{OH})_{5} \cdot 2 \mathrm{H}_{2} \mathrm{O}$, a new mineral from the Hagendorf South pegmatite, Germany. Mineral Petrol 111: 351-361

Chukanov NV, Aksenov SM, Rastsvetaeva RK, Schäfer C, Pekov IV, Belakovskiy DI, Scholz R, DE Oliveira LCA, Britvin SN (2017) Eleonorite, $\mathrm{Fe}^{3+}{ }_{6}\left(\mathrm{PO}_{4}\right)_{4} \mathrm{O}(\mathrm{OH})_{4} \cdot 2 \mathrm{H}_{2} \mathrm{O}$ : validation as a mineral species and new data. Mineral Mag 81: 61-76

Frost RL, López A, Scholz R, Xi Y, Lana C (2014) The molecular structure of the phosphate mineral beraunite $\mathrm{Fe}^{2+} \mathrm{Fe}_{5}^{3+}\left(\mathrm{PO}_{4}\right)_{4}(\mathrm{OH})_{5} \cdot 4 \mathrm{H}_{2} \mathrm{O}-$ a vibrational spectroscopic study. Spectrochim Acta Part A 128: 408-412 
Gagné OC, Hawthorne FC (2015) Comprehensive derivation of bond-valence parameters for ion pairs involving oxygen. Acta Crystallogr B71: 562-578

Hawthorne FC (1994) Structural aspects of oxide and oxysalt crystals. Acta Crystallogr B50: 481-510

Hawthorne FC (2012) A bond-topological approach to theoretical mineralogy: crystal structure, chemical composition and chemical reactions. Phys Chem Miner 39: $841-874$

HAwTHORNE FC (2015) Toward theoretical mineralogy: a bond-topological approach. Amer Miner 100: 696-713

HAWTHORNE FC, SCHINDLER M (2008) Understanding the weakly bonded constituents in oxysalt minerals. Z Kristallogr 223: 41-68

JARCHOVSKÝ T (2006) The nature and genesis of greisen stocks at Krásno, Slavkovský les area - western Bohemia, Czech Republic. J Czech Geol Soc 51: 201-216

LibowitzKy E (1999) Correlation of O-H stretching frequencies and $\mathrm{O}-\mathrm{H} \cdots \mathrm{O}$ hydrogen bond lengths in minerals. Monatsh Chem 130: 1047-1059

MerLet C (1994) An accurate computer correction program for quantitative electron probe microanalysis. Microchim Acta 114/115: 363-376

Mills SJ, Kolitsch U, Birch WD, Sejkora J (2008) Kunatite, $\mathrm{CuFe}_{2}\left(\mathrm{PO}_{4}\right)_{2}(\mathrm{OH})_{2} \cdot 4 \mathrm{H}_{2} \mathrm{O}$, a new member of the whitmoreite group, from Lake Boga, Victoria, Australia. Austral J Mineral 14: 3-12

Mills SJ, Kampf AR, Sejkora J, Adams PM, Birch WD, PLÁŠIL J (2011) Iangreyite: a new secondary phosphate mineral closely related to perhamite. Mineral Mag 75: 327-336

Mills SJ, Sejkora J, Kampf AR, Grey IE, Bastow TJ, Ball NA, Adams PM, RAudsepp M, CoOper MA (2012) Krásnoite, the fluorophosphate analogue of perhamite, from the Huber open pit, Czech Republic and the Silver Coin mine, Nevada, USA. Mineral Mag 76: 625-634

Moore PB (1970) Crystal chemistry of the basic iron phosphates. Amer Miner 55: 135-169

Moore PB, Kampf AR (1992) Beraunite: refinement, comparative crystal chemistry, and selected bond valences. Z Kristallogr 201: 263-281
PETŘíčEK V, DuŠEK M, PALATINus L (2014) Crystallographic Computing System Jana2006: general features. Z Kristallogr 229: 345-352

RigAKu (2018) CrysAlis CCD and CrysAlis RED. RigakuOxford Diffraction Ltd, Yarnton, Oxfordshire, UK

Rruff Project (2019). R060464 Beraunite. Department of Geosciences, University of Arizona. Accessed on October 23, 2019, at http://rruff.info/beraunite/display=default

Scholz R, Frost RL, Xi Y, Graça LM, Lagoeiro L., López A. (2013) Vibrational spectroscopic characterization of the phosphate mineral phosphophyllite $\mathrm{Zn}_{2} \mathrm{Fe}\left(\mathrm{PO}_{4}\right)_{2} \cdot 4 \mathrm{H}_{2} \mathrm{O}$, from Hagendorf Süd, Germany and in comparison with other zinc phosphates. J Mol Struct 1039: 22-27

SeJkora J, ŠKoda R, Ondruš P, Beran P, SüsSER C (2006) Mineralogy of phosphate accumulations in the Huber Stock, Krásno ore district, Slavkovský les area, Czech Republic. J Czech Geol Soc 51: 103-147

SeJkora J, Plášil J, Filip J (2011) Plimerite from Krásno near Horní Slavkov ore district, Czech Republic. J Geosci 56: 215-229

SeJkora J, Grey IE, Kampf AR, Price JR, Čejka J (2016) Tvrdýite, $\mathrm{Fe}^{2+} \mathrm{Fe}^{3+}{ }_{2} \mathrm{Al}_{3}\left(\mathrm{PO}_{4}\right)_{4}\left(\mathrm{OH}_{2}\right)_{4} \cdot 2 \mathrm{H}_{2} \mathrm{O}$, a new phosphate mineral from Krásno near Horní Slavkov, Czech Republic. Mineral Mag 80: 1077-1088

Sejkora J, Tvrdý J, ČEJKA J, VRTišKa L, DolníčEK Z (2019a) Bendadaite from Krásno near Horní Slavkov (Czech Republic), description and Raman spectroscopy. Bull Mineral Petrolog 27: 63-71

Sejkora J, Grey IE, KampF AR (2019b) Kenngottite, $\mathrm{Mn}_{3}^{2+} \mathrm{Fe}^{3+}{ }_{4}\left(\mathrm{PO}_{4}\right)_{4}(\mathrm{OH})_{6}\left(\mathrm{H}_{2} \mathrm{O}\right)_{2}$ : a new phosphate mineral from Krásno near Horní Slavkov, Czech Republic. Eur J Mineral 31: 629-636

SHELDRICK GM (2015): SHELXT - Integrated space-group and crystal-structure determination. Acta Crystallogr A71: 3-8

VrtišKa L, Sejkora J, Malíková R (2018) Arthurite from Huber Stock in Krásno near Horní Slavkov - the first occurrence in the Czech Republic. Bull Mineral Petrolog 26: 74-77 (in Czech) 